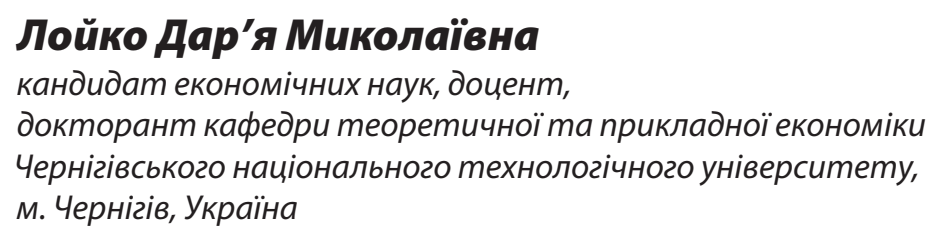

\title{
ДИНАМІКА СПОЖИВАННЯ ПРОДУКТІВ ХАРЧУВАННЯ У ДОМОГОСПОДАРСТВАХ УКРАЇНИ ТА ЧЕХІЇ
}

\begin{abstract}
Анотація. У статmі розглянуто динаміку споживання продуктів харчування у домогосподарствах України та Чехії за період 2013-2017 рр. Зроблено висновок про зростання сукупних ресурсів домогосподарств України за період 2010-2017 рр. на 82,64\% і відповідно зростання витрат за той же період на 86,88 \%. Перевищення динаміки зростання середньомісячних витрат над середньомісячними доходами на одне домогосподарство України склало 4,24\%. Питома вага споживчих витрат домогосподарств України у 2017 р. склала 93,0\% від загальних витрат. Валовий грошовий дохід на людину в рік в Чехії за період 2013-2017 рр. зріс на 19,67\%, сукупні витрати на споживання за той період зросли на 8,35\%. Перевищення динаміки зростання доходів на одну людинув рік над зростанням витрат у домогосподарствах Чехії склало 11,32 \%. Витрати на споживання у чеських родинах склали у 2017 р. 63,36\%. Домогосподарства України на статтю витрат «продукти харчування та безалкогольні напої» витратили у 2017 р. 51,2\% сімейного бюджету. Чеські родини витрачають на продукти харчування на 31,3\% менше, ніж українські родини. За результатами проведеного дослідження зроблено наступні висновки. Рівень споживання продуктів харчування у домогосподарствах Чехії за період 2013-2017 рр. зріс, зокрема: м'яса на 7,35\%, фруктів - 6,77\%, овочів - 6,39\%, молока та молочних продуктів - 5,29\%, чукру - 4,49\%, хлібопродуктів - 1,01\%. Рівень споживання продуктів харчування у домогосподарствах України за 2013-2017рр. знизився, зокрема: риби на 27,78\%, оліі - 11,76\%, фруктів - 9,76\%, овочів - 6,38\%, картоплі-5,63\%, чукру - 6,67\%, хліба - 6,67\%, м'яса - 3,92\%. У порівняльній характеристичі споживання продуктів харчування домогосподарства Чехії спожили у 2017 р. більще ніж домогосподарства України: фруктів на 84,68\%, м'яса - 36,56 \%, яєць - 5,83 \%, мучних виробів - 12,59 \% та менше: олії на 72,22 \%, риби - 65,38\%, овочів - 16,48 \%, картоплі - 14,80\%. Зроблено висновок, що рівень життя домогосподарств Чехії вищий ніж рівень життя домогосподарств України.
\end{abstract}

Ключові слова: Україна, Чехія; домогосподарства; ресурси; витрати; споживання; продукти харчування; порівняльний аналіз; рівень життя.

DOI: http://doi.org/10.32750/2018-0109

$\mathcal{D}_{3 a}^{\mathrm{CT}}$

\section{СТП}

Постановка проблеми.

а рахунок розвитку глобалізаційних процесів, міжнародного співробітництва та міжнародних зв'язків більшість товарів і послуг стають доступнішими для людей різних країн. За дослідженнями економістів обсяги споживання різних товарів та послуг у світі із року у рік зростають. Споживчий сектор економіки кожної окремої країни значно впливає на національну економіку в цілому. Домогосподарства виступають повноцінними і самостійними учасниками економічних відносин у кожній країні. Враховуючи євроінтеграційне спрямування розвитку української економіки доцільно провести порівняльний аналіз споживчих витрат на продукти харчування українських домогосподарств та домогосподарств європейської країни,

№1 (2018) 
наприклад, Чехії з метою виявлення тенденцій змін обсягів та структурних зрушень, як характеристики рівня життя населення.

Аналіз останніх досліджень і публікацій. Теоретико-методичним аспектам оцінки життєвого рівня населення, його взаємозалежності від рівня економічного розвитку країни, визначення масштабів бідності в країні, формуванню соціальної політики, а також питанням оцінки життєвого рівня населення за доходами та витратами домогосподарств присвячені праці вчених: Кізими Т.О., Рамського А.Ю., Червоної С.П., Сидорової А.В., Коваленко А.О., Чабан Г.В., Ревенко А.П. та інших.

Мета статті. Дослідження основних тенденцій та структурних зрушень у споживчих сукупних витратах домогосподарств України та Чехії, зокрема у витратах на продукти харчування, як характеристики якості життя населення.

\section{РЕЗУЛЬТАТИ ДОСЛІДЖЕННЯ}

Фінансова поведінка домогосподарств залежить від багатьох чинників, зокрема: економічної і політичної ситуації в країні, споживчих пріоритетів населення, традицій та звичок, державного регулювання сфери споживання. При нестабільній економічній та політичній ситуації населення схильне до збільшення витрат на споживання i накопичення матеріального багатства. При стабільній економічній та політичній ситуації в країні населення схильне до нарощування обсягів фінансових заощаджень. На фінансову поведінку населення можуть впливати як державна економічна політика так і ринкові важелі, а саме: стабільність та достатність доходів домогосподарств, можливість нарощування ресурсів та заощадження частини доходів, тенденції змін цін на товари і послуги (зростання або зниження), дефіцит або профіцит товарів і послуг, відповідність цін якості товарів та послуг, споживацька поведінка індивідів, вплив реклами на споживацьку поведінку.

Динаміка доходів та споживання у домогосподарствах різних країн $€$ віддзеркаленням економічних та соціальних змін, які відбуваються у суспільстві під впливом різних чинників. Результати дослідження динаміки сукупних ресурсів та сукупних витрат домогосподарств України та Чехії за період 2013-2017 рр. дозволив зробити наступні висновки (табл.1).

Таблиия 1

Динаміка сукупних ресурсів та витрат домогосподарств України та Чехії за період 2013-2017 рр.

\begin{tabular}{|c|c|c|c|c|c|c|}
\hline Показник & 2013 & $2014^{1}$ & $2015^{1}$ & $2016^{1}$ & $2017^{1}$ & $\begin{array}{l}\text { Відхилення } \\
\text { даних 2017 } \\
\text { від 2013, \% }\end{array}$ \\
\hline \multicolumn{7}{|c|}{ Україна } \\
\hline $\begin{array}{c}\text { Сукупні ресурси в середньому на місяць } \\
\text { на одне домогосподарство, грн. }\end{array}$ & 4470,5 & 4563,3 & 5231,7 & 6238,8 & 8165,2 & 82,64 \\
\hline $\begin{array}{c}\text { Сукупні витрати в середньому на місяць } \\
\text { на одне домогосподарство, грн. }\end{array}$ & 3820,3 & 4048,9 & 4952,0 & 5720,4 & 7139,4 & 86,88 \\
\hline \multicolumn{7}{|l|}{ 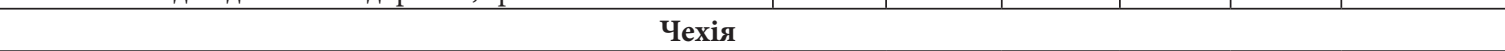 } \\
\hline Валовий грошовий дохід на людину в рік (CZK) & 166087 & 177430 & 183536 & 192575 & 198764 & 19,67 \\
\hline Витрати на споживання на людину в рік (CZK) & 116244 & 120827 & 122049 & 122467 & 125947 & 8,35 \\
\hline
\end{tabular}

Примітки: ${ }^{1}$ - офіційні дані за 2014-2017 рр. наведено без урахування тимчасово окупованої території Автономної Республіки Крим і м. Севастополя.

Джерело: складено автором за даними $[1,2]$.

Обсяг сукупних ресурсів домогосподарств України за період 2010-2017 рр. зріс на 82,64\% і відповідно відбулося зростання витрат за той же період на 86,88\%. Перевищення динаміки зростання середньомісячних витрат над середньомісячними доходами на одне домогосподарство України склало 4,24\%. Питома вага споживчих витрат домогосподарств України у 2017 р. склала 93,0\% від загальних витрат. Валовий грошовий дохід на людину в рік в Чехії за період 2013-2017 pp. зріс на 19,67 \%, сукупні витрати на споживання за той період зросли на 8,35\%. Перевищення динаміки зростання доходів на одну людину в рік над зростанням витрат у домогосподарствах Чехії склало $11,32 \%$. Витрати на споживання у чеських родинах склали у 2017 р. 63,36 \%. Таким чином можна зробити наступні висновки:
- зростання обсягів як сукупних ресурсів так і сукупних витрат у чеських домогосподарствах за період 2013-2017 рр. відбувалось повільнішими темпами, ніж у домогосподарствах України за той же період;

- темпи зростання витрат у домогосподарствах України перевищили темпи зростання ресурсів за досліджуваний період на $4,24 \%$;

- темпи зростання доходів у домогосподарствах Чехії перевищили темпи зростання витрат за досліджуваний період на 11,32 $\%$;

- чеські родини витрачають на споживання менше ресурсів, ніж українські, на 29,64\%, що дозволяє робити чеським родинам заощадження на майбутні витрати. 
За результатами проведеного порівняльного аналізу динаміки структурних зрушень у статтях споживчих витрат домогосподарств України та Чехії, які стосуються статей витрат «продукти харчування та безалкогольні напої» та «алкогольні напої і тютюн» за період 20132017 pp. (табл.2) можна зробити наступні висновки.

Таблиия 2

Динаміка структурних зрушень споживчих витрат домогосподарств України та Чехії за період 2013-2017 рр., \%

\begin{tabular}{|c|c|c|c|c|c|c|}
\hline Показник & $2014^{1}$ & $2015^{1}$ & $2016^{1}$ & $2017^{1}$ & $2014^{1}$ & $\begin{array}{c}\text { Відносна зміна } \\
(2017 / 2013), \%\end{array}$ \\
\hline \multicolumn{7}{|c|}{ Продукти харчування та безалкогольні напої } \\
\hline Україна & 50,1 & 51,9 & 52,6 & 49,8 & 51,2 & 2,19 \\
\hline Чехія & 19,3 & 20,2 & 20,3 & 20,0 & 19,9 & 3,11 \\
\hline \multicolumn{7}{|c|}{ Алкогольні напої, тютюн } \\
\hline Україна & 3,5 & 3,4 & 3,1 & 2,9 & 3,0 & $-14,29$ \\
\hline Чехія & 2,8 & 2,8 & 2,8 & 2,9 & 2,9 & 3,57 \\
\hline
\end{tabular}

Примітки: 1 - офіційні дані за 2014-2017 рр. наведено без урахування тимчасово окупованої території Автономної Республіки Крим і м. Севастополя.

Джерело: складено автором за даними $[1,2]$.

Споживчі витрати домогосподарств України на продукти харчування та безалкогольні напої за досліджуваний період зросли на 2,19\% і склали у бюджетах родин у 2017 р. 51,2 \%. Споживчі витрати на продукти харчування та безалкогольні напої у чеських родинах за той же період зросли на 3,11 \% та склали у 2017 р. 19,9\%, що на 31,3 \% менше, ніж в українських родинах. Витрати на алкогольні напої та тютюн в українських домогосподарствах за період 2013-2017 рр. знизились на 14,29 \%, а в чеських домогосподарствах зросли на 3,57 \%.

За рівнем доходів домогосподарства України поділено на 10 децильних груп. До першої групи віднесено домогосподарства із найнижчим рівнем середньодушових еквівалентних загальних доходів (у 2017 р. - до 1920,0 грн. у місяць). До десятої децильної групи віднесено домогосподарства із найвищим рівнем середньодушових еквівалентних загальних доходів (у 2017 р. - понад 5160 грн. у місяць). За проведеними дослідженнями домогосподарства України із вищим рівнем доходів споживають більше м'яса, риби, молока, фруктів, овочів та цукру, ніж домогосподарства із нижчим рівнем доходів. Таких продуктів як яйця, хліб, картопля та олія домогосподарства із високим та низьким рівнем доходів споживають майже однаково [3].

Для проведення порівняльного аналізу споживання продуктів харчування у домогосподарствах України та Чехії дослідження приймаємо дані 6 децильної групи, для якої рівень загальних доходів на одну особу домогосподарстві у 2017p. склав 3720,1-4080,0 грн.

Порівняльний аналіз розподілу споживання продуктів харчування в залежності від доходів у домогосподарствах України та Чехії за 20132017 рр. дозволив зробити наступні висновки (табл. 3).

Таблиия 3

Динаміка розподілу споживання продуктів харчування у домогосподарствах України та Чехії за період 2013-2017 рр. (у середньому за рік у розрахунку на 1 особу, кг)

\begin{tabular}{|c|c|c|c|c|c|c|c|c|}
\hline \multirow{4}{*}{$\begin{array}{c}\text { Назва } \\
\text { продуктів харчування }\end{array}$} & \multicolumn{6}{|c|}{ Обсяги споживання продуктів харчування за рік на одну особу } & \multirow{3}{*}{\multicolumn{2}{|c|}{$\begin{array}{c}\text { Відносне } \\
\text { відхилення даних } \\
2017 \text { р. від даних } \\
2013 \text { р., \% } \\
\end{array}$}} \\
\hline & \multicolumn{3}{|c|}{2013} & \multicolumn{3}{|c|}{2017} & & \\
\hline & \multirow{2}{*}{ Україна } & \multirow{2}{*}{ Чехія } & \multirow{2}{*}{$\begin{array}{l}\text { Відхилення } \\
\text { Чехія / } \\
\text { Україна,\% }\end{array}$} & \multirow{2}{*}{ Україна } & \multirow{2}{*}{ Чехія } & \multirow{2}{*}{$\begin{array}{l}\text { Відхилення } \\
\text { Чехія / } \\
\text { Україна,\% }\end{array}$} & & \\
\hline & & & & & & & Україна & Чехія \\
\hline М'ясо і м'ясопродукти & 61,2 & 74,8 & 22,22 & 58,8 & 80,3 & 36,56 & $-3,92$ & 7,35 \\
\hline Молоко і молочні продукти & 243,6 & 234,0 & $-3,94$ & 243,6 & 246,4 & 1,15 & - & 5,29 \\
\hline Яйця, шт. & 240 & 243 & 1,25 & 240 & 254 & 5,83 & - & 4,53 \\
\hline Риба і рибопродукти & 21,6 & 5,3 & $-75,46$ & 15,6 & 5,4 & $-65,38$ & $-27,78$ & 1,89 \\
\hline Цукор & 36,0 & 33,4 & $-7,22$ & 33,6 & 34,9 & 3,86 & $-6,67$ & 4,49 \\
\hline Олія & 20,4 & 5,1 & $-75,0$ & 18,0 & 5,0 & $-72,22$ & $-11,76$ & $-1,96$ \\
\hline Картопля & 85,2 & 68,0 & $-20,19$ & 80,4 & 68,5 & $-14,80$ & $-5,63$ & 0,74 \\
\hline Овочі & 112,8 & 82,9 & $-26,51$ & 105,6 & 88,2 & $-16,48$ & $-6,38$ & 6,39 \\
\hline Фрукти & 49,2 & 76,8 & 56,09 & 44,4 & 82,0 & 84,68 & $-9,76$ & 6,77 \\
\hline Хліб та мучні вироби & 108,0 & 112,3 & 3,98 & 100,8 & 113,5 & 12,59 & $-6,67$ & 1,01 \\
\hline
\end{tabular}

Примітки: 1 - офіційні дані за 2014-2017 рр. наведено без урахування тимчасово окупованої території Автономної Республіки Крим і м. Севастополя.

Джерело: складено автором за даними $[1,2]$. 
Рівень споживання продуктів харчування у домогосподарствах Чехії за період 2013-2017 pр. зріс, зокрема: м'яса на 7,35\%, фруктів - 6,77\%, овочів - 6,39\%, молока та молочних продуктів $5,29 \%$, цукру - 4,49\%, риби - 1,89 \%, хлібопродуктів - 1,01\%, картоплі - 0,74 \%; зменшилось тільки споживання олії на 1,96 \%.

Рівень споживання продуктів харчування у домогосподарствах України за 2013-2017pp. знизився, зокрема: риби на 27,78\%, олії - 11, $76 \%$, фруктів - 9,76\%, овочів - 6,38\%, картоплі - 5,63\%, цукру - 6,67\%, хліба - 6,67\%, м'яса - 3,92\%. Зростанню рівня споживання продуктів харчування в українських родинах сприятимуть збільшення ресурсів домогосподарств за рахунок різних джерел та надання державної підтримки сім'ям, зокрема у 2019 р. передбачено збільшення прожиткового мінімум на одну особу в розрахунку на місяць у розмірі 31 січня 2019 року - 1853 гривні, з 1 липня - 1936 гривень, з 1 грудня - 2027 гривень $[4,5]$.

У порівняльній характеристиці споживання продуктів харчування домогосподарства Чехії спожили у 2017 р. більше ніж домогосподарства України: фруктів на 84,68\%, м'яса - 36,56 $\%$, яєць - 5,83 \%, мучних виробів - 12,59 \% та менше: олії на 72,22 \%, риби - 65,38\%, овочів $16,48 \%$, картоплі - 14,80\%.

Таким чином можна зробити висновок, що рівень споживання продуктів харчування у чеських родинах за період 2013-2017 рр. зріс, а в українських зменшився. Безумовно, що на рівень споживання в українських родинах значно вплинули об’єктивні та суб'єктивні чинники, зокрема: погіршення політичної та відповідно економічної ситуації в Україні упродовж 2014-2017 pp. із-за необхідності проведення антитерористичної операції на сході Україні, геополітичні зміни, які викликані анексією території Автономної Республіки Крим та м. Севастополя, високий рівень макроекономічної нестабільності, спад ділової активності, закриття багатьох підприємств та зниження рівня їх доходності.

\section{ВИСНОВКИ ТА ПЕРСПЕКТИВИ ПОДАЛЬ- ШИХ ДОСЛІДЖЕНЬ}

Процес глобалізації світової економіки впливає на динаміку та структуру споживання домогосподарств у різних країнах світу. Уніфікація та переплетення культур різних країн формує нові зразки споживацької поведінки та збільшує обсяги споживання товарів та послуг в всьому світі. Досліджуючи поведінку споживачів, доцільно вивчати не тільки динаміку змін обсягів споживання (зростання або зменшення), зокрема продуктів харчування, а й яку частину доходів витрачають на це домогосподарства у різних країнах.

Зростання рівня доходів та заощаджень домогосподарств у світі визнається як рівень зростання добробуту населення. За проведеним аналізом динаміки обсягів доходів, витрат та заощаджень домогосподарств України, можна зробити висновок щодо зростання рівня споживчих витрат, зокрема на продукти харчування, які становили у 2017 р. 51,2 \% від загальних сукупних витрат українських родин. За період 2013-2017 pp. домогосподарства України знизили рівень споживання майже всіх продуктів харчування, окрім яєць та молока, які залишились на незмінному рівні. Зниження рівня добробуту домогосподарств України та зростання витрат на споживання несе ризики нарощування бідності населення. За проведеним аналізом рівня доходів та витрат домогосподарств Чехії можна зробити висновок, щодо домогосподарства Чехії менше витрачають на споживання, зокрема на продукти харчування, та мають можливість накопичувати заощадження. Рівень споживання усіх видів продуктів (крім олії) у домогосподарствах Чехії за період 2013-2017 pр. зріс. Таким чином можна зробити висновок, що рівень життя домогосподарств Чехії вищий, ніж домогосподарств України.

\section{СПИСОК ВИКОРИСТАНИХ ДЖЕРЕЛ}

1. Офіційний сайт Державної служби статистики України. Статистична інформація. Доходи та умови життя: [Електронний ресурс] — Режим доступу до: www.ukrstat.gov.ua.

2. Чеський статистичний уряд. Статистична інформація. [Електронний ресурс] - Режим доступу до: https://www.czso.cz/csu/czso/zivotni_uroven_spotreba_domacnosti_prace

3. Лойко Є.М. Динаміка споживання продуктів харчування у домогосподарствах України /Лойко Є.М., Пилипенко A.І.// Сучасна фінансова політика України: проблеми та перспективи [Текст]: матеріали v Всеукраїнської науково-практичної конференції,(м. Київ, 29 листопада 2018 р.) / Київський університет імені Бориса Грінченка.- Київ, 2018. - С. 93-95.

4. Про затвердження набору продуктів харчування, наборів непродовольчих товарів та наборів послуг для основних соціальних і демографічних груп населення: Постанова Кабінету Міністрів України №780 від 11.10.2016: [Електронний ресурс] — Режим доступу до: http://zakon.rada.gov.ua/ laws/show/780-2016-\%D0\%BF

5. Про державний бюджет України на 2019 рік: Закон України № 2629-VIII від 23.11. 2018: [Електронний ресурс] — Режим доступу до: http://search.ligazakon.ua/1_doc2.nsf/link1/T182629.html 


\author{
Лойко Дарья Николаевна \\ кандидат экономических наук, доцент, \\ докторант кафедры теоретической и прикладной экономики \\ Черниговского начионального технологического университета, \\ 2. Чернигов, Украина \\ ORCID ID: 0000-0002-2443-2719 \\ e-mail: loyko_d@i.ua
}

\begin{abstract}
Аннотация. $B$ статье рассмотрена динамика потребления продуктов питания в домохозяйствах Украины и Чехии за период 2013-2017 г2. Сделан вывод о росте совокупных ресурсов домохозяйств Украины за период 2010-2017 г2. на 82,64\% и соответственно рост расходов за тот же период на 86, 88\%. Превышение динамики роста среднемесячных расходов над среднемесячными доходами на одно домохозяйство Украины составило 4,24\%. Удельный вес потребительских расходов домохозяйств Украины в 2017 г. составил 93,0\% от общих расходов. Валовой денежный доход на человека в год в Чехии за период 2013-2017 г2. вырос на 19,67\%, совокупные затраты на потребление за тот же период выросли на 8,35\%. Превышение динамики роста доходов на одного человека в год над ростом расходов в домохозяйствах Чехии составило 11,32\%. Расходы на потребление в чешских семьях составили в 2017 г. 63,36\%. Домохозяйства Украины на статью расходов «продукты питания и безалкогольные напитки» потратили в 2017 г. 51,2\% семейного бюджета. Чешские семьи тратят на продукты питания на 31,3\% меньше, чем украинские семьи. По результатам проведенного исследования сделаны следующие выводы. Уровень потребления продуктов питания в домохозяйствах Чехии за период 2013-2017 г2. вырос, в частности: мяса на 7,35\%, фруктов - 6,77\%, овощей - 6,39\%, молока и молочных продуктов - 5,29\%, сахара - 4,49\%, хлебопродуктов - 1,01\%. Уровень потребления продуктов питания в домохозяйствах Украины в 2013-2017рр. снизился, в частности:рыбы на 27,78\%, масла - 11,76\%, фруктов - 9,76\%, овощей - 6,38\%, картофеля - 5,63\%, сахара 6,67\%, хлеба - 6,67\%, мяса - 3,92\%. В сравнительной характеристике потребления продуктов питания домохозяйства Чехии потребили в 2017 г. больще чем домохозяйства Украины: фруктов на 84,68\%, мяса - 36,56\%, яиц - 5,83\%, мучных изделий - 12,59\% и меньше: масла на 72,22\%, рыбы - 65,38\%, овощей - 16,48\%, картофеля - 14,80\%. Сделан вывод, что уровень жизни домохозяйств Чехии выше, чем уровень жизни домохозяйств Украины.
\end{abstract}

Ключевые слова: Украина, Чехия; домохозяйства; ресурсы; затраты; потребление; продукты питания; сравнительный анализ; уровень жизни.

\title{
DYNAMICS OF CONSUMPTION OF FOODSTUFFS IN HOUSEHOLDS OF UKRAINE AND CZECH REPUBLIC
}

\author{
Daria Loiko \\ Ph.D. (Economics), \\ Associate Professor, doctoral student, \\ Chernihiv National University of Technology, \\ Chernihiv, Ukraine \\ ORCID ID: 0000-0002-2443-2719 \\ e-mail: loyko_d@i.ua
}

\begin{abstract}
The article deals with the dynamics of consumption of food products in households in Ukraine and the Czech Republic for the period of 2013-2017. The conclusion is made of an increase in aggregate household resources in Ukraine for the period 2010-2017 by $82.64 \%$ and, accordingly, the growth of expenses for the same period by $86,88 \%$. The excess of the dynamics of growth of average monthly expenditure over average monthly incomes per household of Ukraine was $4.24 \%$.

The lion's share of consumer spending of households in Ukraine in 2017 amounted to 93.0\% of total expenditures. Gross cash income per person per year in the Czech Republic for the period 2013-2017 grew by $19.67 \%$. Total consumption expenditures for that period increased by $8.35 \%$. The excess of the dynamics of income growth per person per year over the growth of expenditure in households in the Czech Republic amounted to $11.32 \%$. Consumer expenditure in Czech families amounted to $63.36 \%$ in 2017. Households in Ukraine spent in 2017 on the expenditure item "food and soft drinks" 51.2\% of the family budget.
\end{abstract}


Czech families spend on food products $31.3 \%$ less than Ukrainian families. According to the results of the study, the following conclusions were made:

- the level of consumption of food in households in the Czech Republic for the period 2013-2017 increased, in particular: meat - by $7.35 \%$, fruit - 6.77\%, vegetables - 6.39\%, milk and dairy products - 5.29\%, sugar - 4.49\%, bakery products - $1.01 \%$;

- the level of food consumption in households in Ukraine for 2013-2017 decreased by $27.78 \%$, including oil $11.76 \%$, fruits - $9.76 \%$, vegetables - 6.38\%, potatoes - 5.63\%, sugar - 6.67\%, bread - 6, 67\%, meat $3.92 \%$.

In the comparative characteristic, consumption of household food products in the Czech Republic consumed in 2017 was more than households in Ukraine: fruits at 84.68\%, meat - 36.56\%, eggs - 5.83\%, flour products $-12.59 \%$ and less : $72.22 \%$ oil, fish $-65.38 \%$, vegetables $-16.48 \%$, potatoes $-14.80 \%$. The conclusion is that the standard of living of households in the Czech Republic is higher than the standard of living of Ukrainian households.

Key words: Ukraine, Czechia; households; resources; expenses; consumption; food; comparative analysis; standard of living.

\section{REFERENCES (TRANSLATED AND TRANSLITERATED)}

1. Official site of the State Statistics Service of Ukraine. Revenues and living conditions. (2017). Retrieved September 7, 2018, from http://www.ukrstat.gov.ua/table/table_2017/1_4_doh_um_zhytr.htm. [in Ukrainian].

2. Czech Statistical Office. Living Standards, Household Consumption. (2018, May 22). Retrieved September 15, 2018, from https://www.czso.cz/csu/czso/zivotni_uroven_spotreba_domacnosti_prace. [in Czech].

3. Loiko, E. (2018). Dynamics of food consumption in households in Ukraine. Suchasna Finansova Polityka Ukrainy Problemy Ta Perspektyvy,93-95. Retrieved October 29, 2018. [in Ukrainian].

4. Resolution of the Cabinet of Ministers of Ukraine. On approval of a set of food products, sets of non-food products and sets of services for the main social and demographic groups. (2016, October 11). Retrieved October 03, 2018, from http://zakon.rada.gov.ua/laws/show/780-2016-п. [in Ukrainian].

5. Law of Ukraine. About the state budget of Ukraine for 2019. (2018, November 23). Retrieved November 24, 2018, from http://search.ligazakon.ua/1_doc2.nsf/link1/T182629.html. [in Ukrainian]. 